\begin{tabular}{|l|l|l|}
\hline \multicolumn{2}{|c|}{ PublisherInfo } \\
\hline \hline PublisherName & $:$ & BioMed Central \\
\hline \hline PublisherLocation & $:$ & London \\
\hline \hline PublisherImprintName & $:$ & BioMed Central \\
\hline \hline
\end{tabular}

\title{
Variations on a splice theme
}

\begin{tabular}{|l|l|l||}
\hline \multicolumn{2}{|c|}{ ArticleInfo } \\
\hline \hline ArticleID & $:$ & 4901 \\
\hline \hline ArticleDOI & $:$ & $10.1186 /$ gb-spotlight-20031223-01 \\
\hline \hline ArticleCitationID & $:$ & spotlight-20031223-01 \\
\hline \hline ArticleSequenceNumber & $:$ & 253 \\
\hline \hline ArticleCategory & $:$ & Research news \\
\hline \hline ArticleFirstPage & $:$ & 1 \\
\hline \hline ArticleLastPage & $:$ & 3 \\
\hline \hline & & RegistrationDate : 2003-12-23 \\
ArticleHistory & $:$ & OnlineDate \\
\hline \hline ArticleCopyright & $:$ & BioMed Central Ltd2003-12-23 \\
\hline \hline ArticleGrants & $:$ & \\
\hline \hline ArticleContext & $:$ & 130594411 \\
\hline \hline
\end{tabular}




\section{Cathy Holding}

Email: cholding@hgmp.mrc.ac.uk

Based on expressed sequence tag (EST) studies and transcriptome analysis, alternative splicing of premessenger RNAs (pre-mRNAs) occurs in a temporal and tissue-specific manner. In the December 19 Science, Jason Johnson and colleagues at Rosetta Inpharmatics report a systematic survey method to capture all possible splice variants that provides experimental evidence and tissue distributions for several thousand known and novel splice isoforms. These data demonstrate that ESTs are biased toward more highly expressed transcripts and that they underrepresent central regions of cDNAs. This suggests that more than $74 \%$ of human multi-exon genes are alternatively spliced and provides possible novel therapeutic targets for diseases that are caused by inappropriate transcript splicing events (Science 2003, 302:2141-2144).

Johnson et al. used a set of five microarrays containing 125,000 36 bp exon-exon junction probes from 10,000 multi-exon genes to examine 52 tissue samples. Hybridization intensities were modeled as a function of tissue-specific expression levels, which gave an exon-by-exon representation of probable splice events. From these, 150 reverse transcription polymerase chain reaction primer pairs were developed to test for the events across the 52 tissue samples, resulting in a genome-wide set of tissuespecific alternative splice event predictions. Splicing events not represented by ESTs were found (e.g., in the 3-hydroxy-3-methyl-glutaryl coenzyme A reductase gene encoding the targets for the statin class of cholesterol-lowering drugs). Of 153 transcript regions tested, 134 contained alternative splice events not represented by mRNAs, and 92 not represented by ESTs. Seventy three were validated by sequencing, and 53 of these were found to be novel. In addition, using the Gene Ontology database, 31 genes with the highest frequency of alternative splice variants were observed to encode proteins involved in cell communication - such as receptor tyrosine kinases - and in enzyme regulation, such as small GTPase regulation.

Although still problematic in that exon-exon junction arrays cannot determine whether two splicing events in one tissue are present in the same or separate transcripts and that differential expression in tissues is required in order to detect novel splice isoforms, the authors conclude, "This array-guided approach provides evidence of tissue-specific alternative splicing in thousands of genes and has allowed us to identify and sequence-verify splice variants not represented currently by ESTs or mRNAs."

All expression data are freely available in the Gene Expression Omnibus database.

\section{References}


1. Mechanisms of alternative pre-messenger RNA splicing

2. Science, [http://www.sciencemag.org/]

3. Rosetta Inpharmatics, [http://www.rii.com/]

4. Gene Expression Omnibus, [http://www.ncbi.nlm.nih.gov/geo] 